УДК: 636:612.1:636.4

doi: $10.36359 /$ scivp.2019-20-2.29

\title{
ВАРІАЦІЙНО-ПУЛЬСОМЕТРИЧНЕ ДОСЛІДЖЕННЯ КРОЛІВ
}

М. В. Закревська, аспірант,

А. М. Тибінка, д-р вет. наук, професор

Львівський національний університет ветеринарної медицини та біотехнологій

імені С. 3. Гжицького,

вул. Пекарська, 50, Львів, 79010, Україна

У статті охарактеризовано особливості тонусу автономних нервових центрів у кролів-самиів (Oryctolagus cuniculus) породи Термонська біла. Для цього всім тваринам записали електрокардіограму, на основі якої провели математичний аналіз варіабельності $R$ $R$ кардіоінтервалів з визначенням таких показників: мода, амплітуда моди, варіачійний розмах та інших. Отримані результати дозволили зробити висновок про сукупний тонус симпатичних та парасимпатичних цеентрів у кожного кроля $і$ на основі цього всіх тварин розділити на три групи. Найчисленнішу групу (70\% дослідних тварин) сформували кролісимпатотоніки, які характеризуються домінуванням тонусу симпатичних иентрів над парасимпатичними. Ці тварини мають найвищий показник амплітуди моди $і$ найнижчі значення моди та варіаційного розмаху. До другої (за чисельністю тварин) групи ввійшли кролі-нормотоніки (19\%), які характеризуються зрівноваженим симпатичним та парасимпатичним тонусом, тому більшість досліджених показників займають середне значення. Третя група була найменш численною (11\%) і включала кролів-парасимпатотоніків, у яких парасимпатичний тонус домінуе над симпатичним. Тварини характеризуються найбільшими показниками моди та варіаційного розмаху і найменшою величиною амплітуди моди. Такі варіачійно-пульсометричні показники, як мода та варіаційний розмах, володіють кореляційними зв'язками з масою тіла кролів. Характер цих зв'язків певною мірою залежить від групи тварин. Сама маса тіла набуває найбільших значень у кролів-парасимпатотоніків. У двох інших груп тварин вона є меншою. 3 варіаційно-пульсометричними показниками тісно пов'язана частота сериевих скорочень, найбільщі значення якої спостерігалися у кролівсимпатотоніків, середні величини відповідали кролям-нормотонікам, а мінімальні показники - кролям-парасимпатотонікам.

Ключові слова: КРОЛІ, СЕРЦЕВИЙ РИТМ, ВАРІАЦІЙНА ПУЛЬСОМЕТРІЯ, СИМПАТОТОНІКИ, НОРМОТОНІКИ, ПАРАСИМПАТОТОНІКИ, ТИП НЕРВОВӦ̈ СИСТЕМИ.

Дослідження серцевого ритму (пульсометрія), як діагностичний метод, вже тривалий час викликає зацікавлення науковців. Зміни у серцевому ритмі та коливання стінок судин відмічали у своїх працях Гален, Руф Ефеський, Бянь Цяо та ін. Проте, математичний аналіз варіабельності кардіоінтервалів почали застосовувати лише у другій половині 20 ст. Саме тоді Р. М. Баевский розробив його для дослідження стану серцево-судинної та нервової систем людей та тварин, які готувалися до польотів в космос [1]. На даний час, варіаційну пульсометрію застосовують для прогнозування захворювань та визначення функціональних можливостей серця та судин у спортсменів [2, 3], а також при вивчені захворювань інших органів, зокрема головного мозку [4-6]. Цей метод дозволяє, на основі аналізу серцевого ритму, охарактеризувати особливості загального тонусу автономної нервової системи. Три відділи останньої регулюють функціональні параметри серцевого м'яза: симпатичний відділ (нейрони бокових рогів грудного сегмента спинного мозку) - здійснюють стимулюючий 
вплив; парасимпатичний відділ (блукаючий нерв) - здійснює пригнічуючий вплив; метасимпатичний відділ (провідникова система серця) - забезпечує автоматизм. При цьому, різне поєднання тонусу симпатичного та парасимпатичного відділів встановлює відповідний тип автономних впливів на міокард. $[1,7]$. Метою даної роботи було вивчити типологічні особливості автономної регуляції в організмі кролів-самців породи Термонська біла.

Матеріали і методи. Для дослідження використали 27 кролів-самців (Oryctolagus cuniculus) породи Термонська біла, віком 4 міс. Для проведення електрокардіографічного дослідження тварин протягом доби тримали на голодній дієті, а також видаляли шерстний покрив: в ділянці зап’ястка на передній правій лапі, в ділянці заплесни на задній лівій лапі, в ділянці грудини. Запис електрокардіограми проводили без використання наркозу. Тваринам надавали спинного положення та на звільнені від шерсті ділянки накладали електроди 3 марлевою прокладкою, яку попередньо змочували у сольовому розчині. Для запису електрокардіограми використали реограф (модель - Р4-02), що має електрокардіографічний канал, а також реєструючий прилад (модель Н338-6П). Швидкість протяжки стрічки при записі кардіосигналу становила 250 мм/с. На отриманих кардіограмах, за допомогою кардіологічної лінійки, досліджували величину R-R інтервалів, кількість яких становила 100. При цьому, визначили такі показники: моду (Mo) - величина інтервалу R-R, який трапляється найчастіше, амплітуду моди (AMo) - кількості (виражена у \%) інтервалів R-R, що формують моду, $\Delta \mathrm{x}$ - варіаційний розмах - різниця між найдовшим та найкоротшим інтервалами R-R. 3 вищевказаних показників математично вираховували похідні показники: IAP - індекс автономної рівноваги ( IAP $=\mathrm{AMo} / \Delta \mathrm{x})$, АПР - автономний показник ритму $(\mathrm{AПP}=1 / \mathrm{Mo} \times \Delta \mathrm{x})$, $\mathrm{IH}-$ індекс напруження регуляторних систем $(\mathrm{IH}=\mathrm{AMo} / 2 \times \mathrm{Mo} \times \Delta \mathrm{x})$ (Баевский та ін., 1984). Також на основі кардіограми визначили частоту серцевих скорочень у тварин.

На основі отриманих результатів, дослідних кролів поділили на три групи: кроліпарасимпатотоніки (ПС) - 3 тварини - характеризуються домінуванням тонусу парасимпатичних центрів, кролі-нормотоніки (НT) - 5 тварин - мають зрівноважений тонус симпатичного та парасимпатичного відділів та кролі-симпатотоніки (СТ) - 19 тварин характеризуються домінуванням тонусу симпатичних центрів.

У всіх тварин, при допомозі ваги МК-15,2-ТН20, визначали масу тіла.

Статистичне опрацювання результатів досліджень проводили за допомогою програми «StatPlus2008». При цьому, визначали: х - вибіркове середнє, SD - стандартна помилка середнього. Групу симпатотоніків приймали за основу і з нею порівнювали показники двох інших груп. Достовірність різниці показників між групами кролів подавали у формі: * $\mathrm{P}<0,05 ; * *-\mathrm{P}<0,01 ; * * *-\mathrm{P}<0,001$.

Результати й обговорення. Результати проведених досліджень дозволяють побачити, що кожна тварина характеризується індивідуальними особливостями тонусу симпатичних та парасимпатичних центрів, що відображається у відмінностях варіаційно-пульсометричних показників. У сукупному результаті це появляється формуванням певного типу автономних впливів в організмі тварин (табл.).

Табличя

Показники варіаційно-пульсометричного дослідження

\begin{tabular}{|l|c|c|c|}
\hline \multirow{2}{*}{ Показники } & \multicolumn{3}{|c|}{ Групи кролів } \\
\cline { 2 - 4 } & Симпатотоніки & Нормотоніки & Парасимпатотоніки \\
\hline Частота серцевих скорочень, уд./хв. & $248,17 \pm 7,02$ & $229,09 \pm 15,0$ & $204,38 \pm 10,88$ \\
\hline Мо, с & $1,21 \pm 0,02$ & $1,4 \pm 0,04 * * *$ & $1,43 \pm 0,07 * * *$ \\
\hline AMо, \% & $24,6 \pm 1,65$ & $17,6 \pm 0,68^{*}$ & $11,3 \pm 0,89^{* *}$ \\
\hline$\Delta \mathrm{x}, \mathrm{c}$ & $0,09 \pm 0,006$ & $0,18 \pm 0,02^{* * *}$ & $0,45 \pm 0,2 * * *$ \\
\hline IAP & $273,33 \pm 37,7$ & $99,95 \pm 9,71$ & $25,11 \pm 9,32$ \\
\hline AПР & $10,02 \pm 0,67$ & $4,18 \pm 0,46 * * *$ & $2,11 \pm 0,61 * * *$ \\
\hline IH & $111,82 \pm 16,77$ & $36,83 \pm 4,24$ & $8,75 \pm 2,9$ \\
\hline
\end{tabular}

Примітка: ${ }^{*}<0,05-* ;<0,01-* * ;<0,001$-*** 
У кролів-нормотоніків та кролів-парасимпатотоніків показники моди приблизно однакові, проте значно більші ніж у тварин-СТ. Кролі-НТ переважають їх на 0,19 с $(\mathrm{P}<0,001)$, а кролі-ПС на 0,22 с $(\mathrm{P}<0,001)$. Ці дані вказують на швидше серцебиття у кролівсимпатотоніків, так як їхні інтервали R-R (повне серцеве скорочення) коротші. За даними Гаврилової, 2012 зростання величини моди свідчить про підвищення адаптованості організму [8]. Імовірно, кролі-НТ та ПС здатні краще пристосовуватися до умов навколишнього середовища та менш чутливі до його змін.

Частота появи однакових кардіоінтервалів дає можливість визначити AMo, яка вказує на рівень стабільності серцевих скорочень. У тварин-симпатотоніків даний показник найвищий. Кролі-НТ поступаються їм на 7 \% (P<0,05), а кролі-ПС на 13,3 \% (P<0,01). Коркушко та ін. встановили, що зростання амплітуди моди свідчить про домінування симпатичної нервової регуляції [9].

Варіаційний розмах, як $\mathrm{i}$ амплітуда моди, характеризує стабільність серцевих скорочень. Проте ці два показники обернено пропорційні. Якщо зростає АМо, то варіаційний розмах знижується. Вважається, що цей показник відображає вплив парасимпатичної нервової системи [9]. Тому, кролів з найвищим $\Delta \mathrm{x}$ відносять до групи парасимпатотоніків і вони на 0,36 c $(\mathrm{P}<0,001)$ переважають групу-СТ. У кролів-нормотоніків різниця дещо менша, їхній показник $\Delta \mathrm{x}$ перевищує показник симпатотоніків на 0,09 с $(\mathrm{P}<0,001)$.

Наступні показники обчислюються на основі попередніх і дозволяють більш комплексно охарактеризувати автономний тонус.

Індекс автономної рівноваги змінюється за рахунок АМо та $\Delta \mathrm{x}$ i вказує на співвідношення симпатичної та парасимпатичної автономної регуляції серцевого ритму. Таким чином, прослідковується закономірність, при якій IAP зростає при високому показнику АМо та низькому $\Delta \mathrm{x}[1,11]$. Це виражено у кролів-СТ. На противагу їм, група-ПС, у яких найнижчий показник AМо та найвищий $\Delta \mathrm{x}$, що призводить до зниження IAP на 248,22 одиниці порівняно з кролями-симпатотоніками. Тварини-НТ займають середню позицію, а їхній IАР нижчий від кролів-СТ на 173,38 одиниць.

Автономний показник ритму характеризує парасимпатичну складову загального автономного тонусу. Тому, низькі його значення вказують на зростання парасимпатичних впливів в організмі тварин [10, 11]. Відповідно, серед досліджених груп кролів найвищі значення АПР відповідали тваринам-СТ, кролі-нормотоніки поступаються їм на 5,84 одиниць $(\mathrm{P}<0,001)$. Зрозуміло, що найменше значення АПР належить кролям-ПС.

Індекс напруженості регуляторних систем, який ще називають стрес-індексом, дозволяє зрозуміти яким шляхом формується сукупний тонус автономних центрів у кожного організму. Це має важливе значення, оскільки, симпатотонія може виникати на фоні підвищеного симпатичного тонусу і нормального парасимпатичного тонусу, або на фоні нормального симпатичного тонусу i зниженого парасимпатичного тонусу. Аналогічні варіанти характерні і для формування парасимпатотонії. Високі значення IH вказують на низьку витривалість організму і низькі пристосувальні рефлекси $[1,11]$. Це найбільш виражено у кролів-симпатотоніків. Значно нижчий (на 74,99 одиниць) даний показник у групі HТ. I найменший IН у кролів-ПС (на 103,07 одиниць нижчий порівняно з СТ).

Для візуалізації відмінностей варіаційно-пульсометричних показників для кожної групи тварин побудовано варіаційну гістограму (рис. 1-3). 


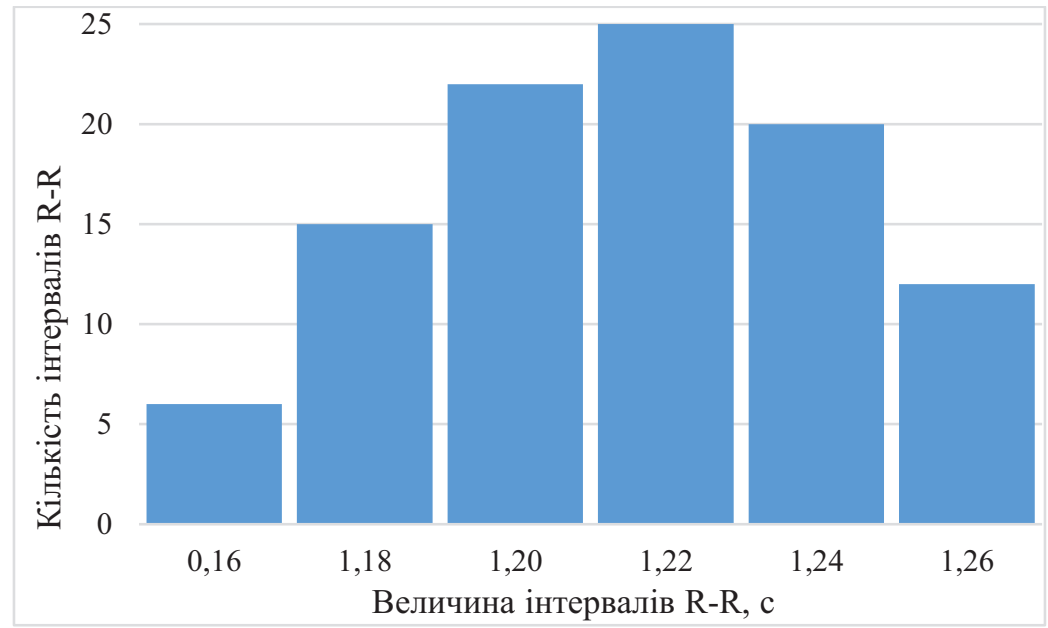

Puc. 1. Варіаційна гістограма кролів-симпатотоніків.

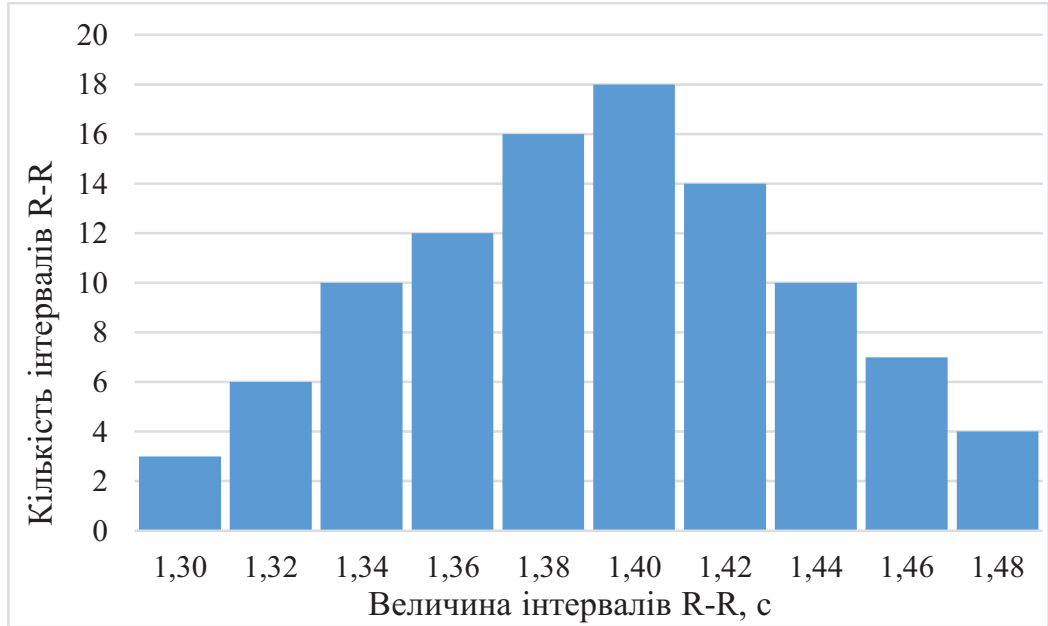

Puc. 2. Варіаційна гістограма кролів-нормотоніків.

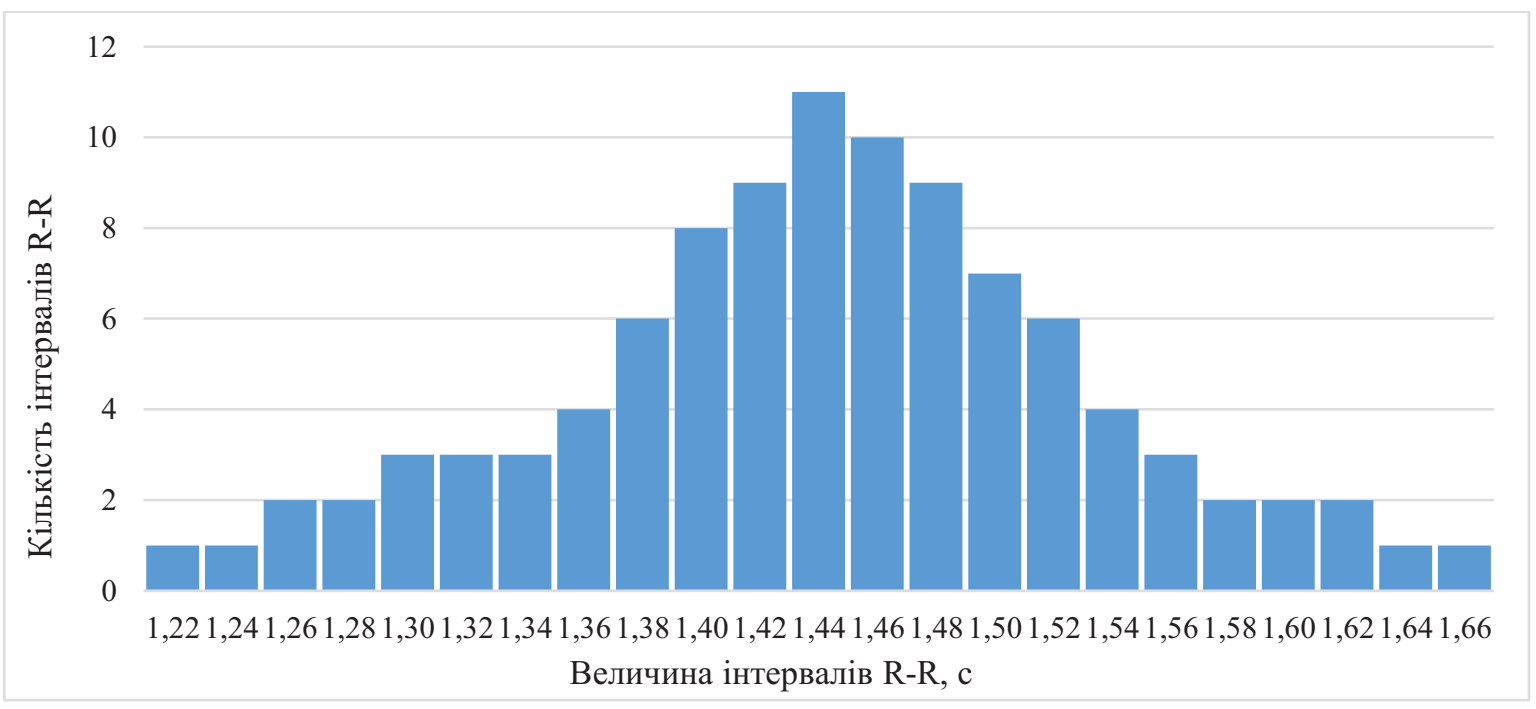

Рис.3. Варіаційна гістограма кролів-парасимпатотоніків.

Варіаційна гістограма кролів-симпатотоніків за тривалістю R-R інтервалів зміщена в сторону їх мінімальних значень, має вузьку основу та найбільшу висоту. У кролівнормотоніків тривалість інтервалів R-R, та діапазон їх величин збільшується. Тому варіаційна гістограма тварин цієї групи стає ширшою та нижчою. У кролів-парастимпатиків інтервали R- 
$\mathrm{R}$ стають найтривалішими та найбільш варіативними. Це обумовлює максимальну ширину варіаційної гістограми та її мінімальну висоту.

Оскільки автономна нервова система кролів-симпатотоніків, характеризується домінуванням симпатичного тонусу, тому вона перебуває в стані певного постійного напруження. Внаслідок цього, тварини важче адаптуються до навколишніх змін та є менш стійкими до стресів порівняно з кролями інших груп. Це знаходить своє відображення у частоті серцевих скорочень та масі тіла досліджених тварин. Очевидним є те, що найбільша

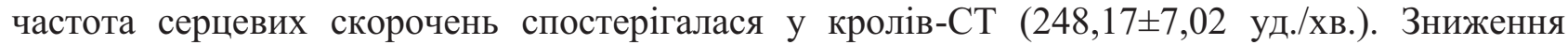
симпатичних впливів у кролів-НТ супроводжується зменшенням цього показника на 19,08 уд./хв. Ще рідшим пульс стає внаслідок посилення парасимпатичних впливів у кролівПС - 204,38 $\pm 10,88$ уд./хв., що $є$ на 43,79 уд./хв. меншим порівняно з симпатотоніками.

Що до маси тіла, то кролі-ПС характеризувалися ii найбільшим значенням -

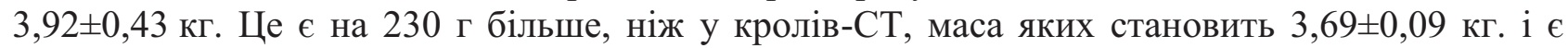
найнижчою серед досліджуваних груп. У тварин-нормотоніків маса тіла $3,8 \pm 0,19$ кг, різниця між ними та кролями-СТ складає 120 г.

На зв’язок між показниками серцевого ритму та масою тіла також вказують результати кореляційного дослідження. Так, у тварин-СТ встановлено прямий середній кореляційний зв'язок між масою тіла та показником Мо $(\mathrm{r}=0,35)$ і слабкий прямий зв'язок між масою тіла та $\Delta \mathrm{x}(\mathrm{r}=0,13) . \mathrm{У}$ кролів-НТ теж спостерігається прямий середній кореляційний зв'язок між вказаними показниками, проте він $є$ дещо вищим ніж в попередній групі і відповідно становить $\mathrm{r}=0,69, \mathrm{r}=0,60$. Найбільш сильні кореляційні зв'язки встановлено у тварин-ПС. Між масою тла та Мо цей зв'язок є зворотнім ( $\mathrm{r}=-1)$, а між масою тіла та $\Delta \mathrm{x}-$ прямий $(\mathrm{r}=0,88)$.

\title{
В И С Н О В К И
}

1. У досліджених кролів встановили три типи автономного тонусу: симпатикотонію (70 \% тварин), нормотонію (19 \% тварин) та парасимпатикотонію (11\% тварин).

2. Кролям-СТ відповідають найвищі значення АМо на фоні найнижчих показників Мо та $\Delta \mathrm{x}$. У тварин-ПС виявлено протилежну ситуацію - найнижчий показник АМо та найвищі показники Мо та $\Delta \mathrm{x}$.

3. Маса тварин має найбільші значення у кролів-ПС і найменші - у кролів-СТ, а також корелює з показниками моди та варіаційного розмаху.

Перспективи досліджень. Дослідити вплив різних типів автономного тонусу на особливості структури внутрішніх органів кролів.

\section{VARIATION-PULSOMETRIC STUDY OF RABBITS}

\author{
M. Zakrevska, A. Tybinka
}

Stepan Gzhytskyi National University of Veterinary Medicine and Biotechnologies, 50, Pekarska Str., Lviv, 79010, Ukraine

\section{S U M M A R Y}

The article describes the features of the tonus of autonomic nerve centers in male rabbits (Oryctolagus cuniculus) of Termond White breed. For this purpose, an electrocardiografic study was performed for all animals. The received data enabled to conduct a mathematical analysis of the variability of R-R cardio intervals, defining such indicators as mode, mode amplitude, variational range, etc.

The obtained results allowed to draw conclusions regarding the total tonus of the sympathetic 
and parasympathetic centers for each rabbit and, based on this, divide all the animals into three groups. The largest group, i.e. $70 \%$ of the animals under experiment, was formed by sympathicotonic rabbits, which were characterized by the predominance of the tonus of sympathetic centers over that of the parasympathetic ones. In this group, the value of mode amplitude is the highest, while both mode and variation range are the lowest.

The second group included normotonic rabbits (19\%), which were characterized by a balanced sympathetic and parasympathetic tonus. That's why most of the studied parameters are of the average value. The third group was the least numerous $(11 \%)$ and included parasympathetic rabbits in which the parasympathetic tonus dominated the sympathetic one. Animals were characterized by the highest values of mode and variational range and the smallest value of mode amplitude.

Such variation-pulsometric indicators as mode and variational rage correlate with the body weight of rabbits. To a certain extent, the nature of these relationships depends on the group of animals. The body weight reaches its largest values in parasympathetic rabbits. In the other two animal groups, it is smaller.

Variation-pulsometric indices are closely related to the heart rate, the highest values of which were observed in sympathicotonic rabbits, while average meanings referred to normotonic rabbit and the lowest values were found among parasympatheticotonic rabbits.

Keywords: RABBITS, HEART RHYTHM, VARIATION PULSOMETRY, SYMPATHICOTONIC RABBITS (ST), NORMOTONIC RABBITS (NT), PARASYMPATHETICOTONIC RABBITS (PS), TYPE OF NERVOUS SYSTEM.

\title{
ВАРИАЦИОННО-ПУЛЬСОМЕТРИЧЕСКОЕ ИССЛЕДОВАНИЕ КРОЛИКОВ
}

\author{
М. В. Закревская, А. М. Тьбинка
}

Львовский национальный университет ветеринарной медицины и биотехнологий
имени С.3. Гжицкого,
ул. Пекарская, 50, Львов, 79010, Украина

А Н Н О Т А ЦИЯ

В статье охарактеризированы особенности тонуса автономных нервных центров у кроликов-самцов (Oryctolagus cuniculus) породы Термонская белая. Для этого всем животным записали электрокардиограмму, на основе которой провели математический анализ вариабельности R-R кардиоинтервалов с определением следующих показателей: мода, амплитуда моды, вариационный размах и других. Полученные результаты дали возможность сделать вывод о совокупном тонусе симпатических и парасимпатических центров, у каждого кролика и на основе этого всех животных разделить на три группы. Самую многочисленную группу (70 \% подопытных животных) сформировали кролики-симпатотоники, которые характеризируются преобладанием тонуса симпатических центров над парасимпатическими. Эти животные имеют самый высокий показатель амплитуды моды и низкие значения моды и вариационного размаха. Ко второй (по численности животных) группе вошли кроликинормотоники (19 \%), которые характеризуются уравновешенным симпатическим и парасимпатическим тонусом, поэтому большинство исследованных показателей занимают среднее значение. Третья группа была самой малочисленной $(11 \%)$ и включала кроликовпарасимпатотоников, в которых парасимпатический тонус доминирует над симпатическим. Животные характеризируются наибольшими показателями моды и вариационного размаха и наименьшей величиной амплитуды моды. Такие вариационно-пульсометрические показатели, как мода и вариационный размах обладают корреляционными связями с массой тела кроликов. 
Характер этих связей в определенной степени зависит от группы животных. Сама масса тела приобретает наибольших значений у кроликов-парасимпатотоников. В двух других группах животных она меньше. С вариационно-пульсометрическими показателями тесно связана частота сердечных сокращений, наибольшие значения которой наблюдались у кроликовсимпатотоников, средние величины отвечали кроликам-нормотоникам, а минимальные показатели - кроликам-парасимпатотоникам.

Ключевые слова: КРОЛИКИ, СЕРДЕЧНЫЙ РИТМ, ВАРИАЦИОННАЯ ПУЛЬСОМЕТРИЯ, СИМПАТОТОНИКИ, НОРМОТОНИКИ, ПАРАСИМПАТОТОНИКИ, ТИП НЕРВНОЙ СИСТЕМЫ.

\section{Л I T E P A T Y P A}

1. Математический анализ изменений сердечного ритма при стрессе / Р. М. Баевский, О. И. Кириллов, С. З. Клецкин и др. - Москва, 1984.- 224 с.

2. Shlyk N. I. Type of autonomic regulation and the risk of heart disease in athletes (based on dynamic studies of HRV and ECG dispersion mapping) / Shlyk N. I., Sapozhnikov E. N., Kirillova T. G. // All-Russian scientific and practical conference "Sports Medicine. Health and physical education. Sochi2012”. - Volgograd, 2012. - P. 17-25.

3. Dynamics of heart rate variability in gymnasts with different type of regulation in the training microcycle / M. G. Dolbinin, L. N. Botova, A. S. Chinkin, T. G. Kirillova // AllRussian scientific-practical conference in memory of prof. N. D. Graevskaya "Sports Cardiology", 2009. - P. $23-24$.

4. Kawamoto $M$. Heart rate variability during artificial ventilation and apnea in brain-damaged rabbits / M. Kawamoto, K. Kaneko, O. Yuge // Am. J. Physiol., 1996. Ed. 271. - P. 410- 416.

5. Positive end-expiratory pressure depressed cardiovascular autonomic nervous system activity in acute brain damaged rabbits under general anesthesia / S. Kurita, M. Kawamoto, S. Hidaka, O. Yuge // Hiroshima J. Med Sci., 2003. - Ed 52. - P. 59-67.

6. Power spectral analysis of heart-rate variability reflects the level of cardiac autonomic activity in rabbits / V. A. Moguilevski, L. Shiel, J. Oliver, B. P. McGrath // J. Auton Nerv Syst., 1996. - Ed. 58. - P. 18-24.

7. Вариабельность сердечного ритма среди кроликов породы шиншилла / К. Ш. Надареишвили, И. И. Месхишвили, Д. Д. Кахиании др. // Бюлл. экспер. биол. и мед., 2002. Вип. 12. - С. 657-659.

8. Гаврилова E. A. Прогнозирование аэробных способностей высококвалифицированных лыжников по данным вариационной пульсометрии / Е. А. Гаврилова, О. А. Чурганов // Вестник спортивной науки. - 2012. - Вип. 4. - С. 3-5.

9. Коркушко О. В. Методология анализа вариабельности ритма сердца: возрастные аспекты / О. В. Коркушко, А. В. Писарук, В. Б. Шатило // Кровообіг та гемостаз. - 2014. - Вип. 3-4. - C. 5-17.

10. Heart rate variability: standards of measurement, physiological interpretation and clinical use. Task Force of the European Society of Cardiology and the North American Society of Pacing and Electrophysiology. - European Heart Journal. - № 17 - 1996. - P. 354-381.

11. Баевский Р. М. Анализ вариабельности сердечного ритма при использовании различных электрокардиографических систем (часть 1) / Р. М. Баевский, Г. Г. Иванов, Л. В. Чирейкин и др. // Весник аритмологии, 2002. - Вип. 24. - С. 65 - 87.

\section{References}

1. Matematicheskiy analiz izmeneniy serdechnogo ritma pri stresse / P. M. Baevskiy. O. I. Kirillov, S. Z. Kletskin. - Moskva , 1984.- 224 s. (in Russian). 
2. Shlyk N. I., Sapozhnikov E. N., Kirillova T. G. Type of autonomic regulation and the risk of heart disease in athletes (based on dynamic studies of HRV and ECG dispersion mapping)/ AllRussian scientific and practical conference "Sports Medicine. Health and physical education. Sochi2012”. - Volgograd, 2012. - P. 17-25.

3. Dolbinin M. G. Dynamics of heart rate variability in gymnasts with different type of regulation in the training microcycle / M. G. Dolbinin, L. N. Botova, A. S. Chinkin, T. G. Kirillova // AllRussian scientific-practical conference in memory of prof. N.D. Graevskaya "Sports Cardiology", 2009. - P. 23-24.

4. Kawamoto $M$. Heart rate variability during artificial ventilation and apnea in brain-damaged rabbits / M. Kawamoto, K. Kaneko, O. Yuge // Am. J. Physiol., 1996. Ed. 271. - P. 410-416.

5. Kurita S. Positive end-expiratory pressure depressed cardiovascular autonomic nervous system activity in acute brain damaged rabbits under general anesthesia / S. Kurita, M. Kawamoto, S. Hidaka, O. Yuge // Hiroshima J. Med Sci., 2003. - Ed 52. - R. 59-67.

6. Moguilevski V. A. Power spectral analysis of heart-rate variability reflects the level of cardiac autonomic activity in rabbits / V. A. Moguilevski, L. Shiel, J. Oliver, B. P. McGrath // J. Auton Nerv Syst., 1996. - Ed. 58. - P. 18-24.

7. Nadareishvili K. Sh. Variabelnost serdechnogo ritma sredi krolikov porodyi shinshilla / K. Sh. Nadareishvili, I. I. Meshishvili, D. D. Kahiani, G. L. Ormotsadze, G. T. Nazarishvili, M. G. Gvasaliya, M. T. Hvedelidze, V. Ya. Sandodze // Byull. eksper. biol. i med., 2002. - Vip. 12. S. 657-659. (in Russian).

8. Gavrilova E. A. Prognozirovanie aerobnyih sposobnostey vyisokokvalifitsirovannyih lyizhnikov po dannyim variatsionnoy pulsometrii / E. A. Gavrilova, O. A. Churganov // Vestnik sportivnoy nauki. - 2012. - Vip. 4. - S. 3-5. (in Russian).

9. Korkushko O. V. Metodologiya analiza variabelnosti ritma serdtsa: vozrastnyie aspektyi / O. V. Korkushko, A. V. Pisaruk, V. B. Shatilo // KrovoobIg ta gemostaz. - 2014. - Vip. 3-4. S. 5-17. (in Russian).

10. Heart rate variability: standards of measurement, physiological interpretation and clinical use. Task Force of the European Society of Cardiology and the North American Society of Pacing and Electrophysiology. - European Heart Journal. - № 17. - 1996. - P. 354-381.

11. Baevskiy, R. M. Analiz variabelnosti serdechnogo ritma pri ispolzovanii razlichnyih elektrokardiograficheskih sistem (chast 1) / R. M. Baevskiy, G. G. Ivanov, L. V. Chireykin, A. P. Gavrilushkin, P. Ya. Dovgalevskiy, Yu. A. Kukushkin, , T. F. Mironova, D. A. Prilutskiy, A. V. Semenov, V. F. Fedorov, A. N. Fleyshman, M. M. Medvedev // Vesnik aritmologii., 2002. - Vip. 24. - S. 65-87. (in Russian).

Рецензент - О. М. Щебентовська, д. вет. н., Львівський національний університет ветеринарної медицини та біотехнологій імені С. 3. Гжицького. 